\title{
KEMAMPUAN UNIT USAHA YAYASAN NURUL HAYAT DALAM MENUNJANG BIAYA OPERASIONAL LEMBAGA AMIL ZAKAT
}

\author{
Novalia Nastiti \\ Mahasiswa Program Studi S-1 Ekonomi Islam - Fakultas Ekonomi dan Bisnis - Universitas \\ Airlangga \\ Imron Mawardi \\ Departemen Ekonomi Syariah - Fakultas Ekonomi dan Bisnis - Universitas Airlangga \\ Email: ronmawardi@gmail.com
}

\begin{abstract}
Amil zaka in zaka institutions has the right as one of eight ashnaf. Their rights are usually used by zaka institutions as operational cost. However, not all of the intitutions whichmanage zaka take amil's right, one of them is Yayasan Nurul Hayat. This institution does not take amil's right and it is independent in its operational cost. To support this operational cost, Yayasan Nurul Hayat establish business unit with utilize its profit.

This study aimed to discover the capability of business unit in supporting operational cost of Yayasan Nurul Hayat. This study used a qualitative approach with descriptive case study method. The selections of informant are using purposive sampling method. Data collection was conducted by semi-structured interviews and documentation. This data is analyzed using descriptive method.

The result of this study shows that Yayasan Nurul Hayat Employments' Salary is taken from business unit's profit. It is also used to give bonus for employments and grow the business unit of Yayasan Nurul Hayat up. From the result of this study, it can be concluded that the business unit which is developed has great capability to support operational cost of Yayasan Nurul Hayat.
\end{abstract}

\section{Keyword: Business Unit, Operational Cost, Yayasan Nurul Hayat}

\section{PENDAHULUAN}

\section{A. Latar Belakang Masalah}

Islam pernah memperoleh kejayaan perekonomian. Hal itu dikarenakan para khalifah Islam mengunakan sistem syariah dalam mengelola perekonomiannya. Pada zaman itu pemasukkan negara didapat dari dana zakat, infaq, shadaqah, ushr, jizyah, kharaj, dan yang lainnya yang sesuai dengan hukum Islam.
Kesejahteraan rakyat muslim pada zaman tersebut dapat dikatakan karena pemerintahan mewajibkan membayar zakat bagi umat muslim. Zakat di wajibkan pada tahun ke-9 Hijrah, sementara shadaqoh fitrah pada tahun ke-2 hijrah (Sudarsono, 2008:256). Zakat merupakan sumber pendapatan utama dalam suatu pemerintahan negara Islam, karena zakat dipandang sebagai bentuk ibadah yang wajib dalam agama Islam. 
Menurut Yasin (2011:11) zakat merupakan salah satu rukun Islam dan menjadi salah satu unsur pokok bagi penegakan syariat Islam. Oleh sebab itu, hukum menunaikan zakat adalah wajib bagi setiap muslim dan muslimah yang telah memenuhi syarat-syarat tertentu. Allah swt berfirman:

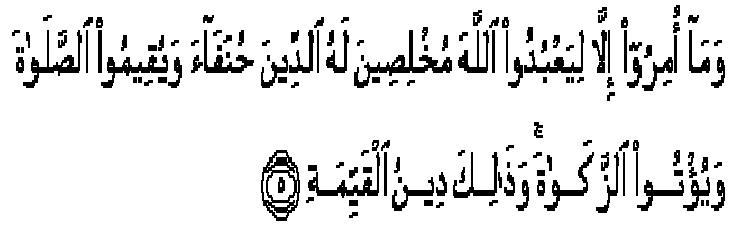

wa māumirūillāli ya'budullaha mukhlișina lahud-din, hunafa'a wa yuqimu'ș-șalaTa wa yu'tuz-zakā̄a wa zalika dinulqayyimah.

"Padahal mereka tidak disuruh kecuali supaya menyembah Allah dengan memurnikan ketaatan kepada-Nya dalam (menjalankan) agama yang lurus,

dan supaya mereka mendirikan salat dan menunaikan zakat. Dan yang demikian itulah agama yang lurus" (QS. al-Bayyinah (98):5)

Zakat dibedakan menjadi dua yaitu zakat maal dan zakat fitrah. Zakat fitrah hanya dibayarkan pada bulan Pembayaran zakat semestinya dapat menghapus tingkat perbedaan yang mencolok antara si fakir dan si kaya, perbedaan tersebut dapat berpengaruh dalam kesenjangan sosial. Serta zakat dapat menciptakan pemerataan harta dalam arti zakat dapat mengentaskan kemiskinan.

Dalam pendayagunaanya, zakat tidak hanya didistribusikan secara
Ramadhan saja, sedangkan zakat maal harus dibayarkan setiap tahun. Zakat maal diambil dari orang-orang yang mampu atau mempunyai harta yang berlebihan atau hartanya sudah mencapai nishab, zakat maal dalam Islam hanya diperuntukkan untuk delapan golongan ashnaf. Delapan golongan ashnaf adalah fakir, miskin, amil zakat, muallaf, hamba sahaya, gharim, fi sabilillah, dan ibnu sabil.

Zakat mempunyai hikmah dan manfaat yang banyak sekali antara lain menghindari kesenjangan sosial antara aghniya dan dhu'afa, membersihkan dan mengikis akhlak yang buruk, alat pembersih harta dan penjagaan dari ketamakan orang jahat, ungkapan rasa syukur atas nikmat yang Allah berikan, untuk pengembangan potensi moral (Sudarsono, 2008:259). Hal ini sejalan dengan firman Allah SWT dalam surah atTaubah: 103

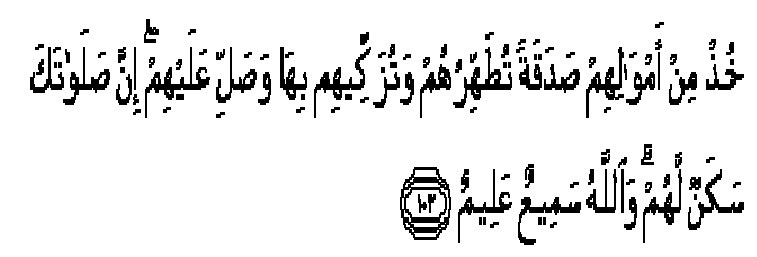

khuż min amwalihim șadaqatan tuțahhiruhum watuzak-kihim biha wa șalli 'alaihim inna șalāaka sakanul lahum wallahu sami'un 'alim

konsumtif, tetapi juga dapat didistribusikan secara produktif. Dengan pendistribusian zakat secara produktif akan memberikan pemasukan bagi para penerima zakat dalam kelangsungan hidupnya. Oleh karena itu, apabila zakat dikelola dengan 
baik, maka zakat akan dapat dipergunakan sebagai sumber dana yang potensial. Pengelolaan zakat ini akan optimal apabila dapat dilakukan secara bersama-sama antara pemerintah, masyarakat, dan lembaga pengelola zakat.

Indonesia penduduknya mayoritas beragama Islam, dengan adanya hal ini potensi pengumpulan dana zakat sangat besar. Hal ini dapat di buktikan dengan berkembangnnya pengelola lembaga zakat yang semakin pesat di Indonesia. Pengelola lembaga zakat sudah banyak yang menerapkan unsur-unsur profesionalisme dan manajemen modern. Berkembangnya pengelola dana zakat dapat dilihat dengan munculannya badan dan lembaga amil zakat baru yang menggunakan pendekatanpendekatan baru yang berbeda dengan sebelumnya.

Pada tahun 1999, pengelolaan zakat sudah disahkan oleh negara. Hal tersebut ditandai dengan disahkannya undang-undang (UU) No38/1999 tentang Pengelolaan Zakat. UU inilah yang menjadi landasan legal formal pelaksanaan zakat di Indonesia. Undangundang pengelolaan zakat diperbarui pada tahun 2011 yaitu UU No23/2011.

Pengelolaan zakat merupakan hal yang menarik untuk di bahas karena sudah terdapat banyak sekali lembaga amil zakat ataupun badan amil zakat yang beredar di Indonesia. Banyak hal yang menarik untuk di bahas yaitu bagaimana cara pengumpulan dana zakatnya, bagaimana cara pendistribusian dan pendayagunaan dana zakat yang sudah dikumpulkan, dan bagaimana cara lembaga zakat dapat membiayai operasional yang ada pada lembaga.

Pengumpulan dana zakat dapat dilakukan dengan cara menjemput bola dalam arti amil langsung datang pada muzakki untuk mengambil dana zakat yang akan didistribusikan, dan dapat juga dikumpulkan dengan cara muzakki langsung menyerahkan sendiri kepada lembaga zakat.

Pendayagunaan dapat dibagi menjadi dua yaitu secara konsumtif atau secara produktif. Seperti yang sudah disebutkan penjelasan diatas tadi, bahwa pendistribusian secara produktif lebih bagus dari pada hanya diberikan secara konsumtif. Dikarenakan, dana zakat yang diberikan secara konsumtif tidak akan mendidik mustahiq untuk memperbaiki kehidupannya. Namun, pada dana zakat yang diberikan secara produktif dapat mendidik mustahiq menjadi mandiri untuk mencukupi kehidupannya. Mustahiq tidak hanya berpangku tangan pada pendistribusian dana zakat, melainkan mustahiq dapat menghasilkan pengahasilan dalam usaha yang diberikan melalui dana zakat produktif dan tidak menutup kemungkinan mustahiq dapat menjadi muzakki. Lembaga zakat juga mendistribusikan zakat produktif secara sosial, yaitu dengan cara mendirikan rumah sakit gratis untuk para fakir dan miskin, sekolah 
gratis bagi fakir dan miskin, dan yang lainnya.

Lembaga zakat tentu memiliki biaya operasional untuk mengelola dana zakat. Biaya operasional itu pada umumnya akan di ambilkan dari dana zakat yang menjadi hak amil. Dalam figh zakat, amil zakat memang di perbolehkan untuk mengambil hak nya. Amil berhak mendapatkan bagian maksimal sebesar $12,5 \%$ dari dana zakat yang dikumpulkan. Masih banyak lembaga zakat yang menutupi biaya operasinalnya dengan mengambil hak amil yang termasuk dalam delapan golongan ashnaf (Hafidhuddin, 2003: 140).

Yayasan Nurul Hayat berbeda dengan lembaga zakat yang lain. Yayasan Nurul Hayat membiayai operasionalnya tanpa mengambil hak amil. Yayasan tersebut memiliki unit usaha yang dapat membiayai seluruh operasional yang ada. Unit usaha yang dimiliki tergolong besar karena dari hasil unit usaha tersebut Yayasan Nurul Hayat dapat menjadi yayasan yang mandiri. (sumber: Rama Yuniato, S.H. selaku manajer humas public relation Yayasan Nurul Hayat Surabaya)

Dana ZIS yang ada di Yayasan Nurul Hayat seluruhnya akan didistribusikan untuk kegiatan sosial dan dakwah. Dana ZIS yang terkumpul tidak diambil sedikitpun untuk gaji karyawan dan operasional yayasan tersebut. Hal ini dapat dilihat dari salah satu tabel laporan keuangan Yayasan Nurul Hayat pada bulan november tahun 2013.
Tabel 1.

Laporan Keuangan Yayasan Nurul Hayat Bulan November 2013

\begin{tabular}{|c|c|c|c|}
\hline & $\begin{array}{l}\text { Program / } \\
\text { Kegiatan }\end{array}$ & Sub Total & Total \\
\hline & Zakat & $\begin{array}{l}\text { Rp. } \\
86.523 .075 \\
88\end{array}$ & \\
\hline & $\begin{array}{l}\text { Infaq dan } \\
\text { Shodaqoh }\end{array}$ & $\begin{array}{l}\text { Rp. } \\
2.460 .645 .9 \\
29,32\end{array}$ & \\
\hline & $\begin{array}{l}\text { Orang Tua } \\
\text { Asuh }\end{array}$ & $\begin{array}{l}\text { Rp. } \\
102.710 .674 \\
, 00\end{array}$ & \\
\hline & Hibah & $\begin{array}{l}\text { Rp. } \\
43.000 .000 \\
00\end{array}$ & \\
\hline & Sahabat & $\begin{array}{l}\text { Rp. } \\
150.000,00\end{array}$ & \\
\hline & & & $\begin{array}{l}\text { Rp. } \\
2.926 .639 .0 \\
79,20\end{array}$ \\
\hline & $\begin{array}{l}\text { PAS / } \\
\text { Pesantren } \\
\text { Anak } \\
\text { Sholeh }\end{array}$ & $\begin{array}{l}\text { Rp. } \\
184.047 .659 \\
80\end{array}$ & \\
\hline $\begin{array}{l}\mathrm{L} \\
\mathrm{a} \\
\mathrm{y}\end{array}$ & $\begin{array}{l}\text { Pembang } \\
\text { unan PAS } \\
\text { Gersik }\end{array}$ & $\begin{array}{l}\text { Rp. } \\
159.382 .525 \\
, 00\end{array}$ & \\
\hline $\begin{array}{l}a \\
n \\
a\end{array}$ & $\begin{array}{l}\text { Beasiswa } \\
\text { Yatim }\end{array}$ & $\begin{array}{l}\text { Rp. } \\
253.788 .870 \\
, 00\end{array}$ & \\
\hline D & $\begin{array}{l}\text { Klinik } \\
\text { Dhuafa' }\end{array}$ & $\begin{array}{l}\text { Rp. } \\
133.401 .086 \\
.00\end{array}$ & \\
\hline $\begin{array}{l}a \\
k\end{array}$ & $\begin{array}{l}\text { MATA } \\
\text { BACA }\end{array}$ & $\begin{array}{l}\text { Rp. } \\
\text { 69.517.300, }\end{array}$ & \\
\hline
\end{tabular}




\begin{tabular}{|c|c|c|}
\hline $\begin{array}{l}\text { w } \\
\text { a } \\
\text { h }\end{array}$ & $\begin{array}{l}\text { Pembinaa } \\
\mathrm{n} \quad \text { Majlis } \\
\text { Ta'lim } \\
\text { Abang } \\
\text { Becak }\end{array}$ & 00 \\
\hline & $\begin{array}{l}\text { IBUQU / } \\
\text { Insentif } \\
\text { Bulanan } \\
\text { Guru Al- } \\
\text { Qur'an }\end{array}$ & $\begin{array}{l}\text { Rp. } \\
203.833 .500 \\
, 00\end{array}$ \\
\hline & $\begin{array}{l}\text { TAFAQUR / } \\
\text { Tanda } \\
\text { Cinta } \\
\text { Penghafal } \\
\text { Al-Qur'an }\end{array}$ & $\begin{array}{l}\text { Rp. } \\
74.279 .300 \\
00\end{array}$ \\
\hline & $\begin{array}{l}\text { PILAR } \\
\text { MANDIRI / } \\
\text { Penciptaa } \\
\text { n } \\
\text { Lapangan } \\
\text { Kerja } \\
\text { Mandiri }\end{array}$ & $\begin{array}{l}\text { Rp. } \\
11.609 .000 \\
00\end{array}$ \\
\hline & $\begin{array}{l}\text { SAHABAT / } \\
\text { Santunan } \\
\text { Ibu Hamil } \\
\text { dan } \\
\text { Pengobat } \\
\text { an }\end{array}$ & $\begin{array}{l}\text { Rp. } \\
50.764 .690 \\
00\end{array}$ \\
\hline & $\begin{array}{l}\text { Sekolah } \\
\text { Anak } \\
\text { Sholeh } \\
\text { Nurul } \\
\text { Hayat }\end{array}$ & $\begin{array}{l}\text { Rp. } \\
6.500 .000,0 \\
0\end{array}$ \\
\hline & $\begin{array}{l}\text { Desa } \\
\text { Binaan }\end{array}$ & $\begin{array}{l}\text { Rp. } \\
42.900 .000 \\
00\end{array}$ \\
\hline & DUPRES / & Rp. \\
\hline
\end{tabular}

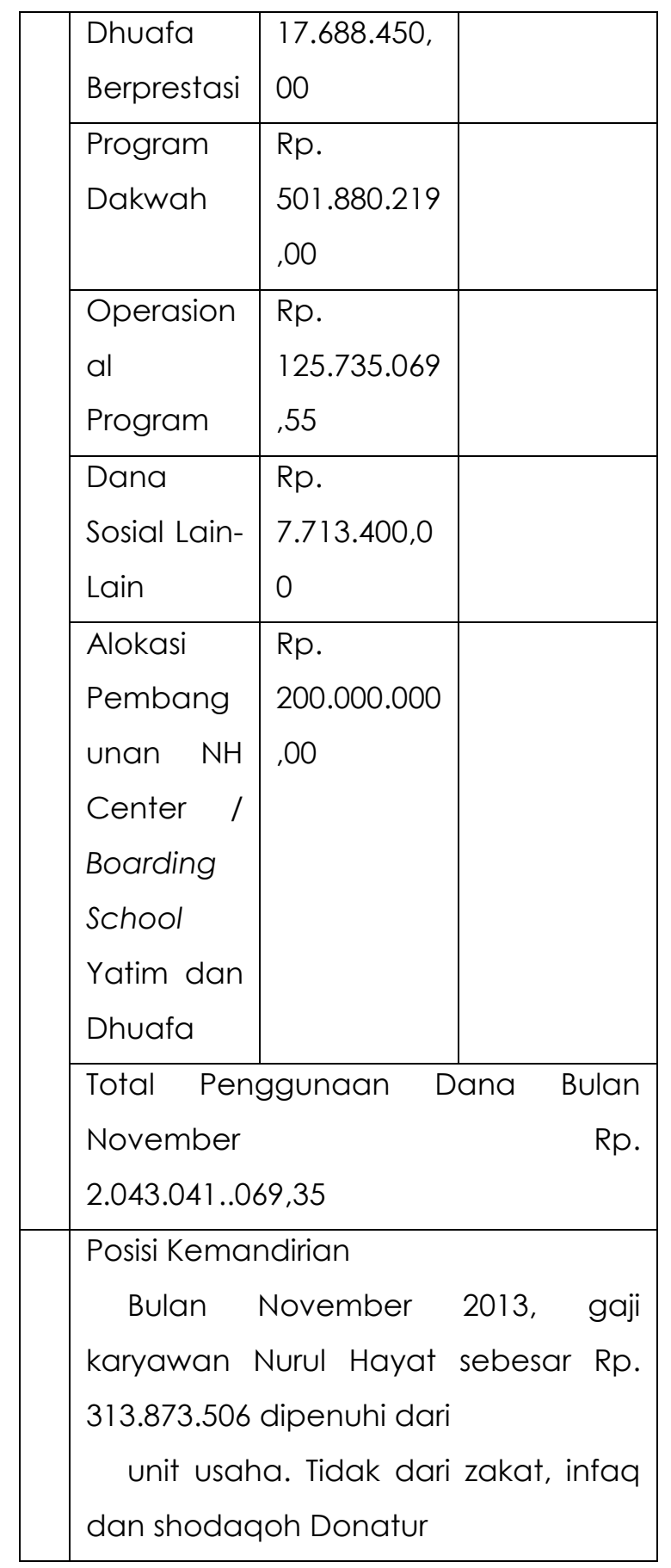

Sumber : NH News Edisi 13 Januari 2014

Yayasan Nurul Hayat memiliki empat unit usaha yang dikembangkan yaitu jasa layanan aqiqah, barang bekas berkualitas (BARBEKU), herbalshop dan percetakan Nusa Hikmah. Tujuan didirikannya unit usaha yaitu agar dana zakat yang terkumpul dapat disalurkan 
secara maksimal untuk kepentingan sosial dan kepentingan dakwah. (sumber: Rama Yuniato, S.H. selaku manajer humas public relation Yayasan Nurul Hayat Surabaya)

Beberapa uraian yang telah dijelaskan sebelumnya, maka munculah suatu permasalahan yaitu bagaimana kemampuan unit usaha dalam menunjang biaya operasional Yayasan Nurul Hayat. Hal ini sangat menarik diteliti karena masih jarang lembaga zakat yang mampu membiayai operasionalnya tanpa mengambil hak amil.

Penelitian ini juga dapat menjadi contoh bagi lembaga zakat lain untuk mengembangkan unit usaha. Penelitian ini berfokus pada "Kemampuan unit usaha dalam menunjang biaya operasional Yayasan Nurul hayat" . Unit Usaha Yayasan Nurul Hayat akan menjadi objek penelitian ini, dikarenakan Yayasan Nurul hayat memiliki unit usaha yang berkebang pesat dan dari keuntungan unit usaha tersebut dapat menutupi biaya operasional yang ada.

\section{B. Rumusan Masalah}

Berdasarkan latar belakang yang telah diuraikan sebelumnya, maka penelitian ini mencoba merumuskan permasalahan yang terkait dengan penelitian guna menjawab permaslahan yang ada. Rumusan maslaha dalam penelitian ini adalah "Bagaimana Kemampuan Unit Usaha Yayasan Nurul Hayat dalam Menunjang Biaya Operasional Lembaga Amil Zakat".

\section{Tujuan Penelitian}

Bedasarkan rumusan masalah yang telah disebutkan sebelumnya, maka tujuan dari penelitian ini adalah untuk mengetahui bagaimana "Kemampuan Unit Usaha Yayasan Nurul Hayat dalam Menunjang Biaya Operasional Lembaga Amil Zakat".".

\section{LANDASAN TEORI PENGEMBANGAN HIPOTESIS}

\section{A. Definisi Zakat}

Ditinjau dari segi bahasa, zakat memiliki banyak arti. Ibnu Arabi menjelakan pengertian zakat dalam beberapa istilah seperti nama" = kesuburan karena dengan zakat maka Allah akan mendatangkan kesuburan pahala, thaharah = kesucian karena zakat merupakan suatu kenyataan jiwa yang suci dari kikir dan dosa, barakah = keberkatan, dan juga tazkiyah, tathhier = mensucikan (Ash Shiddieqy, 2005:3).

\section{B. Hukum Zakat}

Kata zakat dalam Al Qur"an disebutkan sebanyak tiga puluh kali, delapan diantaranya terdapat dalam surah Makiyah. Kata zakat disandingkan dengan kata shalat sebanyak 28 kali (Ash Shiddieqy, 2005 : 4). Dari jumlah ini,dapat kita interpretasikan bahwa perintah zakat sama pentingnya dengan perintah shalat.

$$
\text { Ja'far (1985:16) mengatakan }
$$

apabila ada sekelompok orang muslim enggan menunaikan zakat tanpa mengingkari wajibnya, dan mereka memiliki kekuatan fisik, maka mereka harus ditaklukan sampai mereka mau menyerahkan zakat itu. 


\section{Tujuan Zakat}

Zakat adalah ibadah yang memiliki dua dimensi, yaitu vertikal dan horizontal. Zakat merupakan ibadah sebagai ketaatan kepada Allah (hablu minallah; vertikal) dan sebagai kewajiban kepada sesama manusia (hablu minannas; horizontal). Zakat juga sering disebut sebagai ibadah kesunguhan dalam harta (Hikmat \& Hidayat, 2008:8). Hal tersebut menjadikan zakat tidak hanya sekedar ibadah yang berorientasi pada pahala, namun juga rasa sosial dan kemanusiaan.

\section{Hikmah dan Manfaat Zakat}

Menurut Rifa'l (1996:38-39) zakat merupakan ibadah yang memiliki dimensi ganda, yaitu transedental (berkaitan dengan Sang Khalia) dan horizontal (berkaitan dengan hubungan social kemasyarakatan antar manusia). Oleh sebab itu, zakat memiliki banyak hikmah dalam kehidupan umat manusia, terutama umat Islam, antara lain:

a. Menolong, membantu, membina dan membangun kaum dhu'afa yang lemah untuk memenuhi kebutuhan hidupnya. Dengan kondisi tersebut mereka akan mampu melaksanakan kewajibannya terhadap Allah subhanahu wa ta'ala;

b. Memberantas penyakit iri hati, rasa benci dan dengki dari diri orang-orang yang tidak memiliki apa-apa terhadap orang-orang yang berkecukupan;

c. Mensucikan diri dari dosa, memurnikan jiwa (menumbuhkan akhlak mulia menjadi murah hati, peka terhadap rasa kemanusiaan) dan mengikis sifat kikir serta serakah. Dengan demikian akan muncul suasana ketenangan batin karena terbebas dari tuntutan Allah subhanahu wa ta'ala dan kewajiban kemasyarakatan;

d. Dapat menunjang terwujudnya sistem kemasyarakatan Islam yang berdiri atas prinsip ummatan wahidah (umat yang satu), musawah (persamaan derajat, dan kewajiban), ukhuwah Islamiyyah (persaudaraan Islam) dan takaful ijtima'l (tanggung jawab bersama);

\section{E. Pengertian Fundraising}

$$
\text { Fundraising adalah proses }
$$

mempengaruhi masyarakat baik perseorangan sebagai individu atau perwakilan masyarakat maupun lembaga agar menyalurkan dananya kepada sebuah organisasi (Purwanto, 2009:12). Kata mempengaruhi masyarakat mengandung banyak makna:

\section{F. Tujuan Fundraising}

Ada beberapa hal yang menjadi tujuan dari fundraising bagi sebuah organisasi pengelola zakat:

a. Yang menjadi tujuan poko dari gerakan fundraising adalah pengumpulan dana. Sesuai dengan istilahnya (fundraising) berarti pengumpulan vang. Namun yang dimaksud disini bukanlah vang saja, tetapi dana dalam arti yang luas. Termasuk didalamnya barang dan jasa yang dimiliki nilai materi. Walaupun demikian dana dalam arti vang adalah penting. Mengingat sebuah organisasi nirlaba 
(OPZ) tanpa menghasilkan dana maka tidak ada sumber daya yang dihasilkan. Sehingga apabila sumber day sudah tidak ada maka organisasi akan kehilangan kemampuan untuk terus bertahan menjaga kelangsungan hidupnya. Oleh karena itu bisa dikatakan fundraising yang tidak menghasilkan dana adalah fundraising yang gagal, meskipun memiliki bentuk keberhasilan yang lain.

b. Gerakan fundraising juga bertujuan menghimpun para muzakki dan donatur. OPZ yang baik adalah OPz yang setiap hari memiliki data pertambahan muzakki dan donatur. Sebenarnya yang dibutuhkan adalah pertambahan jumlah dana untuk program pemberdayaan masyarakat beserta operasionalnya. Ada dua hal yang bisa dilakukan oleh OPZ untuk tujuan ini, pertama, menambah jumlah sumbangan dana dari setiap donatur dan muzakki, dan kedua, menambah jumlah donatur dan muzakki itu sendiri.

\section{G. Pendayagunaan Zakat}

Pendayagunaan berasal dari kata "guna" yang berarti manfaat, adapun pengertian pendayagunaan sendiri menurut kamus bahasa Indonesia:

a. Pengusaha agar mampu mendatangkan hasil dan manfaat.

b. Pengusaha (tenaga) agar mampu menjalankan tugas dengan baik.

Dalam Undang-Undang No. 23 tahun 2011 tentang Pengelolaan Zakat, dijelaskan mengenai pendayagunaan adalah :

1. Zakat dapat didayagunakan untuk usaha produktif dalam rangka penanganan fakir miskin dan peningkatan kualitas umat.

2. Pendayagunaan zakat untuk usaha produktif sebagaimana dimaksud pada ayat (1) dilakukan apabila kebutuhan dasar mustahik telah terpenuhi.

3. Ketentuan lebih lanjut mengenai pendayagunaan zakat untuk usaha produktif sebagaimana dimaksud pada ayat (1) diatur dengan Peraturan Menteri.

\section{H. Pendayagunaan Zakat Konsumtif}

1. Konsumtif Tradisional

Maksud pendistribusian zakat secara konsumtif tradisional adalah bahwa zakat dibagikan kepada mustahia dengan secara langsung untuk bebutuhan konsumsi sehari-hari, seperti pembagian zakat fitrah berupa beras dan vang kepada fakir miskin setiap idul fitri atau pembagian zakat mal secara langsung oleh para muzaki kepada mustahiq yang sangat membutuhkan karena ketiadaan pangan atau karena mengalami musibah. Pola ini merupakan program jangka pendek dalam rangka mengatasi permasalahan umat (Fakhruddin, 2008:314).

2. Konsumtif Kreatif

Pendistribusian zakat secara konsumtif kreatif adalah zakat yang diwujudkan dalam bentuk barang konsumtif dan digunakan untuk membantu orang miskin dalam mengatasi 
permasalahan sosial dan ekonomi yang dihadapinya. Bantuan tersebut antara lain berupa alat-alat sekolah dan beasiswa untuk para pelajar, bantuan sarana ibadah seperti sarung dan mukena, bantuan alat pertanian, seperti cangkul untuk petani, gerobak jualan untuk pedagang kecil (Fakhruddin, 2008:314).

\section{Pendayagunaan Zakat Produktif}

1. Produktif Konvensional

Pendistribusian zakat secara produktif konvensional adalah zakat yang diberikan dalam bentuk barang-barang produktif, di mana dengan menggunakan barang-barang tersebut, para muzakki dapat menciptakan suatu usaha, seperti pemberian bantuan ternak kambing, sapi perahan atau untuk membajak sawah, alat pertukangan, mesin jahit (Fakhruddin, 2008:314).

2. Produktif Kreatif

Pendistribusian zakat secara produktif kreatif adalah zakat yang diwujudkan dalam bentuk pemberian modal bergulir, baik untuk pemodalan proyek sosial, seperti pembangunan sosial, seperti pembangunan sekolah, sarana kesehatan atau tempat ibadah maupun sebagai modal usaha untuk membantu atau bagi pengembangan usaha para pedagang atau pengusaha kecil (Fakhruddin, 2008:314).

\section{J. Lembaga Amil Zakat}

Peran amil dijalankan oleh Lembaga Pengelola Zakat yang terdiri dari Badan Amil Zakat dan Lembaga Amil Zakat. Hal ini sesuai dengan UU RI Nomor 23 Tahun 2011 tentang Pengelolaan Zakat, dalam Bab II pasal 5 dan 17. Badan Amil Zakat (BAZ) dibentuk oleh pemerintah, sedangkan Lembaga Amil Zakat (LAZ) dibentuk oleh masyarakat. Menurut Keputusan Presiden Nomor 8 tahun 2001 tentang Badan Amil Zakat Nasional, menjelaskan bahwa Badan Amil Zakat atau Lembaga Amil Zakat sebagai Lembaga Pengelola Zakat yang memiliki kegiatan perencanaan, pengorganisasian, pelaksanaan, dan pengawasan terhadap pengumpulan dan pendistribusian, serta pendayagunaan zakat (Sudarsono, 2007).

\section{K. Pengertian Amil Zakat}

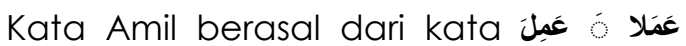
yang biasa diterjemahkan dengan

"yang berbuat, melakukan, pelayan" (Munawwir, 1984:1045). Amil juga bisa diartikan sebagai orang yang mengumpulkan dan mengupayakan zakat (Ar-Rifa'i, 1999:622), juru tulisnya, dan yang membagi-bagikannya (Al-Mahalliy \& As-Suyuthi, 1990:786).

Muhammadiyah Ja'far (2003:71) memberi pengertian yang lebih singkat lagi yaitu orang-orang yang ditugaskan untuk mengumpulkan zakat dari orangorang yang berzakat, dan membagikannya kepada orang-orang yang berhak.

Yang dimaksud dengan amil zakat adalah mereka yang melaksanakan segala kegiatan urusan zakat, mulai dari para pengumpul zakat sampai kepada bendahara dan para penjaganya. Juga mulai dari pencatat sampai kepada penghitung yang mencatat keluar masuk 
zakat dan membagi kepada para mustahiqnya (Qardawi, 2004:545).

\section{Syarat-Syarat Amil.}

Agar tercapai suatu bentuk pengelolaan zakat yang profesional maka diperlukan beberapa syarat bagi para pengelola atau amilnya. Para ulama berselisih paham menyangkut perincian syarat-syarat yang harus dipenuhi oleh seseorang yang diangkat sebagai amil zakat. Seperti yang diutarakan Amien Rais (1994:62-63) bahwa syarat menjadi amil hanya dua yaitu amil harus terdiri dari orang-orang yang memahami ajaranajaran Islam dengan baik dan memiliki kejujuran. Tugas dan Fungsi Amil.

\section{Tugas Amil.}

Pada garis besarnya, para amil dapat dikategorikan menjadi dua kelompok besar: yaitu para pengumpul dan para pembagi. Para pengumpul bertugas mengamati dan menetapkan para muzakki, menetapkan jenis-jenis harta mereka yang wajib dizakati, dan jumlah yang harus mereka bayar. Kemudian mengambil dan menyimpannya untuk diserahkan kepada para petugas yang membagikan apa yang telah mereka kumpulkan itu. Disini para pengumpul sangat memerlukan pengetahuan tentang hukum-hukum zakat, misalnya hal-hal yang berkaitan dengan jenis harta, kadar nishab, haul, dan sebagainya.

Para pembagi bertugas mengamati dan menetapkan, setelah pengamatan dan penelitian yang seksama, siapa saja yang berhak mendapatkan zakat, perkiraan kebutuhan mereka, kemudian membagikan kepada masing-masing yang membutuhkan dengan mempertimbangkan jumlah zakat yang diterima dan kebutuhan mereka masing-masing (Shihab, 1992;328-329). Fungsi Amil.

Menurut Rofiq (2004;274-276), Fungsi amil adalah sebagai:

1. Sebagai mediator antara muzakki dan mustahiq. Agama Islam mengajarkan agar pemeluknya merasa malu untuk meminta-minta, sebagaimana ungkapan bijak "al-yad al-"ulya khair min al-yad al-sufla" artinya "tangan diatas (memberi) lebih baik dari pada tangan di bawah (meminta)".

2. Sebagai lembaga kontrol dan sekaligus mengingatkan para aghniya' agar tidak melupakan kewajibannya menunaikan zakat.

\section{N. Hak Amil}

$\begin{array}{ccc}\text { Demi } & \text { suksesnya } & \text { dan } \\ \text { terpeliharanya } & \text { pengumpulan } & \text { dan }\end{array}$
pembagian zakat, Allah SWT menetapkan bagian yang berhak diterima bagi para petugas zakat dari harta yang dikumpulkannya itu. Hanya saja para ulama berbeda pendapat tentang jumlah yang berhak diterima (Shihab, 1992:329).

Dalam Surat At-Taubah: 60 disebutkan bahwa ada delapan kelompok yang kepada mereka (keseluruhan atau sebagian) diberikan harta zakat yang telah terkumpul, tetapi apakah masing-masing mendapat seperdelapan atau jumlah yang diperoleh masing-masing diserahkan ketetapannya 
kepada kebijaksanaan Imam atau wakilnya.

Ketentuan yang lebih tegas lagi tentang hak atau bagian amil zakat adalah seperti yang diungkapkan Hafidhuddin bahwasanya Amil zakat yang berhak menerima bagian amil zakat secara penuh yaitu seperdelapan (1/8) atau $12,5 \%$ dari jumlah dana zakat yang terkumpul adalah amil yang terdiri dari orang-orang yang disamping amanah, jujur, memahami hukum zakat dengan baik, memiliki kemampuan melaksanakan tugas, juga harus diusahakan full-time dan melaksanakan tugasnya tidak dengan sambilan dan asal-asalan, mengingat tugas amil itu bukan pasif dan diam menunggu datangnya muzakki, tetapi harus aktif melakukan sosialisasi zakat, menjemput zakat, mengadministrasikannya dengan baik, lalu membagikannya dengan tepat sasaran sejalan dengan firman Allah pada Q.S. At-Taubah: 60.

Sedangkan bila sekedar Lajnah (kepanitiaan) biasa seperti yang biasa terjadi sekarang, tidak berhak mengambil penuh jatah atau bagian amil zakat (12,5\%), namun hanya sekedar vang administrasi, transportasi, atau vang lelah yang jumlahnya bisa $1 \%$ atau $2 \%$ atau mungkin setengah dari bagian amil zakat (Hafidhuddin, 2003: 140-142).

\section{O. Kewajiban Amil}

Dilihat dari pengertian amil maka dapat disimpulkan bahwa tugas yang harus dilakukan amil merupakan sebuah kewajiban bagi amil itu sendiri. Yusuf
Qardhawi mengemukakan pendapatnya bahwa para amil zakat mempunyai berbagai tugas dan pekerjaan yang semuanya berhubungan dengan pengaturan soal zakat, yaitu soal sensus terhadap orang-orang yang wajib zakat dan macam zakat, kemudian mengetahui para mustahiq zakat. Berapa jumlah mereka, berapa kebutuhan mereka serta besar biaya yang dapat mencukupi dan hal-hal lain yang merupakan urusan yang perlu ditangani secara sempurna oleh para ahli dan petugas serta para pembantunya (Qardawi, 2004:546).

\section{P. Dana Zakat Diproduktifkan Lembaga}

\section{Zakat}

Dana zakat yang diproduktifkan oeh lembaga zakat dapat pula disebut dengan investasi dana zakat. Dalam syariat Islam, investasi dana zakat ada yang di perbolehkan dan ada yang tidak memperbolehkan.

Fatwa Simposium Yayasan Zakat Internasional III, Tentang Zakat Kontemporer yang diselenggarakan di Kuwait pada tanggal Jumadilakhir 1413.H didalam (Muzammil, 2003:68-67) menyatakan:

Pertama : Penghinvestasian vang zakat

Uang zakat dapat diinvestasikan dengan catatan sebagai berikut :

a. Tidak terdapat alasan yang menuntut penyaluran zakat secara segera.

b. Penginvestasian dilakukan dalam bidang-bidang yang legal.

c. Melakukan semua usaha yang dapat menjamin wujud modal investasi 
termasuk hasilnya tetap sebagai uang zakat.

d. Segera melakukan pencairanuang untuk menyalurkan zakat kepada mustahiqnya bila kondisi menuntut pembayaran.

e. Melakukan tindakan serius mungkin yang menyakinkan bahwa investasi vang zakat itu betul-betul menghasilkan, terjamin dan dapat dicairkan kapanpun.

f. Membuat keputusan yang membatasibahwa pihak yang boleh menginvestasikan zakat tersebut hanya pihak-pihak yang mempunyai wewenang resmi dari Pemerintah untuk mengumpulkan dan menyalurkannya, untuk menjaga prinsip perwakilan resmi serta menyerahkan tugas pengawasannya kepada orang-orang yang ahli, mampu dan jujur.

\section{Q. Pengertian Unit Usaha}

Menurut kamus besar bahasa Indonesia, unit adalah bagian terkecil dari sesuatu yang dapat berdiri sendiri; satuan, sedangkan usaha adalah kegiatan dengan mengerahkan tenaga, pikiran, atau badan untuk mencapai suatu maksud; pekerjaan (perbuatan,prakasa, ikhtiar, daya upaya) untuk mencapai sesuatu. Dapat disimpulkan, bahwa unit usaha adalah kegiatan dengan mengerahkan tenaga, pikiran, atau badan untuk mencapai sesuatu dalam bagian terkecil dari sesuatu yang dapat berdiri sendiri (anak perusahaan).

\section{R. Mengembangkan Usaha menurut Islam}

Menurut Abdullah (2013:13) dalam mengembangakan usaha sesuai syariat islam diperlukan hal-hal berikut:

1. Niat yang baik

2. Berinteraksi dengan akhlak

Akhlak menempati posisi puncak dalam rancang bangun ekonomi Islam, karena inilah yang menjadi tujuan Islam dan dakwah para nabi, yaitu menyempurnakan akhlak.

Beberapa akhlak dasar yang harus dimiliki oleh seorang wirausaha muslim antara lain:

a. Jujur .

b. Amanah

c. Toleran

d. Menepati janji

3. Percaya pada takdir dan ridha

4. Bersyukur

5. Kerja sebagai ibadah

6. Menjaga aturan syariah

\section{S. Pengertiaan Biaya Operasional}

Pengertian biaya operasional yang dikemukakan oleh Jusuf (2008:33) adalah sebagai berikut : "Biaya operasional atau biaya operasi adalah biaya-biaya yang tidak berhubungan langsung dengan produk perusahaan tetapi berkaitan dengan aktivitas operasional perusahaan sehari-hari". Secara umum, biaya operasional diartikan sebagai biaya yang terjadi dalam kaitannya dengan operasi yang dilakukan perusahaan dan diukur dalam satuan vang. Dimana biaya operasi sering disebut juga sebagai operational cost atau biaya usaha. 
Menurut Nafarin (2004: 67) menyatakan bahwa, "Biaya operasi adalah seluruh pengeluaran yang terjadi dalam suatu organisasi guna pelaksanaan aktivitas serta pencapaian tujuan yang telah ditentukan".

\section{METODE PENELITIAN}

\section{A. Pendekatan Penelitian}

Dalam penelitian ini menggunakan pendekatan kualitatif karena peneliti ingin mendapatkan informasi yang lebih lengkap. Selain itu, untuk menjawab pertanyaan penelitian pada rumusan masalah secara lebih mendalam yaitu tentang bagaimana kemampuan unit usaha dalam menunjang biaya operasional Yayasan Nurul Hayat.

Terdapat lima strategi penelitian kualitatif menurut Yin (2009:7), yaitu eksperimen, survei, analisis arsip, historis, dan studi kasus. Dalam penelitian ini akan menggunakan strategi studi kasus untuk memahami masalah yang diteliti.

\section{B. Ruang Lingkup Penelitian}

Penelitian yang dimaksud adalah menjawab rumusan masalah yaitu "Bagaiman kemampuan unit usaha Yayasan Nurul Hayat dalam menunjang biaya operasional Lembaga Amil Zakat?". Rumusan masalah tersebut menjadi acuan dalam penentuan ruang lingkup penelitian. Ruang lingkup penelitian, terbatas pada aktivitas Yayasan Nurul Hayat dalam melakukan pengelolaan unit usaha. Yang menjadi objek dalam penelitian ini pengelolaan unit usaha, serta pengaruhnya terhadap biaya operasional gaji karyawan Yayasan Nurul Hayat.

\section{Jenis dan Sumber Data}

Data dalam penelitian kualitatif dibagi menjadi dua yaitu data primer dan data sekunder. Data primer adalah data yang berasal dari wawancara dan observasi langsung dari lapangan maka datanya lebih banyak berwujud kata-kata dan tindakan dari objek penelitian. Data sekunder adalah data yang sudah ada yang berkaitan dengan penelitian. Sumber dan jenis data dalam penelitian diperoleh dengan cara sebagai berikut :

\section{Data Primer}

Data primer dalam penelitian ini berasal dari key informan (informan kunci). Dalam hal ini yang dimaksud dengan informan kunci, yaitu :

a. Karyawan Yayasan Nurul Hayat yang memahi tentang unit usaha. Hasil wawancara dari penelitian ini diharapkan mendapat informasi tentang gambaran umum yayasan, dan pengelolaan unit usaha.

b. Karyawan Yayasan Nurul Hayat yang memahami tentang biaya operasional yang ada di Yayasan Nurul Hayat.

\section{Data Sekunder}

Data sekunder adalah data penunjang yang digunakan oleh peneliti sebagai pendukung. Data penunjang dalam penelitian ini berasal dari buku-buku terkait dengan zakat, pendistribusian zakat, dan lembaga zakat; hasil-hasil penelitian yang berwujud buku, laporan, jurnal, makalah, internet, dan kajian 
pustaka yang berkaitan dengan permasalahan; serta dokumen yang diperoleh dari Yayayan Nurul Hayat yang berkaitan dengan penelitian.

\section{Prosedur Pengumpulan Data}

Pada

penelitian

yang menggunakan pendekatan kualitatif, terdapat beberapa sumber bukti yang dapat dijadikan sebagai acuan untuk mendukung terlaksananya penelitian. Menurut Yin (2009:103) menjelaskan bahwa ada enam sumber bukti yang dijadikan fokus bagi pengumpul data studi kasus, yaitu: dokumen, rekaman, wawancara, arsip, observasi langsung, observasi pemeran, dan perangkat fisik. Yin (2009:119) selanjutnya menyebutkan tiga prinsip pengumpulan data guna menunjang sumber bukti tersebut, yaitu:

1. Menggunakan Multisumber Bukti

2. Menciptakan Data Dasar Studi Kasus

3. Memelihara Rangkaian Bukti

\section{E. Teknik Analisis}

Analisa data dimaksudkan agar data yang diperoleh dari lapangan dapat dengan mudah dibaca dan dipahami sebagai upaya menemukan jawaban atas permasalahan penelitian. Peneliti menggunakan pendekatan analisis eksplanatori dengan tujuan dapat menganalisis data studi kasus dengan cara membuat suatu penjelasan dari suatu kasus dan membuktikannya guna menguatkan atau menolak argumentasi yang telah ada. Analisis dalam penelitian ini dilakukan dengan cara menjelaskan unit usaha Yayasan Nurul Hayat yang bertujuan sebagai penunjang biaya operasional gaji karyawan LAZ. Hal tersebut dapat dilakukan melalui pengamatan dan wawancara untuk mengetahui lebih dalam kemampuan unit usaha Yayasan Nurul Hayat dalam menunjang biaya operasional Lembaga Amil Zakat.

Analisis yang dilakukan ialah membandingkan penemuan atau buktibukti dengan proposisi yang dibuat peneliti. Menurut Yin (2009:133), tahap analisis data terdiri dari pengujian, pengkategorian, pentabulasian dan pengkombinasian data. Dengan demikian akan muncul proses-proses kejadian dari kasus yang diteliti dan ditemukan makna data yang sesuai dengan tujuan penelitian. 


\section{DESKRIPSI HASIL DAN PEMBAHASAN}

Tabel 2.

\section{Deskripsi Wawancara Informan dari Yayasan Nurul Hayat}

\begin{tabular}{|c|c|c|c|c|}
\hline $\begin{array}{l}\text { Informan I } \\
\text { Rama } \\
\text { Yunianto, } \\
\text { S.H }\end{array}$ & $\begin{array}{l}\text { Sejarah } \\
\text { Nurul Hayat }\end{array}$ & $\begin{array}{l}\text { Awal Mula Adanya } \\
\text { Unit Usaha }\end{array}$ & $\begin{array}{l}\text { Unit Usaha Yayasan } \\
\text { Nurul Hayat }\end{array}$ & \begin{tabular}{l|l} 
Maanfaat Unit Usaha & Penggunaan Hasil \\
Untuk Yayasan Nurul & Laba Unit Usaha \\
Hayat &
\end{tabular} \\
\hline $\begin{array}{l}\text { (HRD } \\
\text { Yayasan } \\
\text { Nurul Hayat) }\end{array}$ & $\begin{array}{l}\text { Pertama kali } \\
\text { Yayaysan Nurul } \\
\text { Hayat berdiri } \\
\text { pada tahun } 2001 . \\
\text { Panti Asuhan } \\
\text { Nurul Hayat } \\
\text { merupakan awal } \\
\text { pendirian } \\
\text { sebelum menjadi } \\
\text { Yayasan Nurul } \\
\text { Hayat }\end{array}$ & $\begin{array}{l}\text { Mendirikan unit } \\
\text { usaha dengan } \\
\text { tujuan supaya } \\
\text { yayasan tidak } \\
\text { mengandalkan } \\
\text { sumbangan para } \\
\text { donatur untuk } \\
\text { biaya operasional } \\
\text { yang ada }\end{array}$ & $\begin{array}{l}\text { Ada empat yaitu, } \\
\text { aqiqah, herbalshop, } \\
\text { BARBEKU, } \\
\text { percetakan Nusa } \\
\text { Hikmah }\end{array}$ & \begin{tabular}{l|l} 
Selain untuk & Hasil usaha yang \\
membiayai seluruh & diterima akan \\
gaji karyawan Nurul & digunakan untuk \\
Hayat, manfaat yang & membiayai seluruh gaji \\
didaptkan yaitu & karyawan yang ada di \\
manfaat moral. & Yayasan Nurul Hayat. \\
Dimana karyawan & Selain itu laba yang \\
lebih percaya diri & masih tersisa akan \\
dalam menerima & digunakan untuk \\
donatur karena & perkembangan usaha. \\
yayasan Nurul Hayat & \\
akan memberikan & \\
dana donatur & \\
tersebeut secara & \\
amanah dan & \\
disalurkan 100\%. &
\end{tabular} \\
\hline $\begin{array}{l}\text { Informan II } \\
\text { Bapak Bayu }\end{array}$ & Modal Awal & $\begin{array}{l}\text { Perkembangan } \\
\text { Usaha }\end{array}$ & Laba Bersih Per & Penggunaan Hasil Laba \\
\hline $\begin{array}{l}\text { Dwi Ratna } \\
\text { (Manager } \\
\text { Unit Usaha } \\
\text { BARBEKU } \\
\text { Yayasan } \\
\text { Nurul Hayat) }\end{array}$ & $\begin{array}{l}\text { Usaha BARBEKU } \\
\text { tidak memerlukan } \\
\text { modal karena } \\
\text { usaha ini } \\
\text { memperoleh } \\
\text { barang dari } \\
\text { shodaqoh dan } \\
\text { akan dijual } \\
\text { kepada } \\
\text { pelanggan. Dari } \\
\text { uang penjual } \\
\text { itulah modal } \\
\text { yang kami dapat } \\
\text { untuk } \\
\text { memperbaiki } \\
\text { barang } \\
\text { shodaqoh yang } \\
\text { belum layak jual. }\end{array}$ & $\begin{array}{l}\text { Bagus, hal ini } \\
\text { dilihat dari } \\
\text { bertambahnya } \\
\text { pendapatan setiap } \\
\text { bulannya. }\end{array}$ & $\begin{array}{l}\text { Laba bersih yang } \\
\text { diperoleh setiap } \\
\text { bulannya } \\
\text { Rp.20.000.000,- } \\
\text { sampai } \\
\text { Rp.30.000.000,- } \\
\text { dengan omset } \\
\text { Rp.40.000.000,- . }\end{array}$ & $\begin{array}{l}\text { Hasil laba usaha digunakan untuk biaya gaji } \\
\text { karyawan Nurul Hayat dan juga } \\
\text { dipergunakan untuk perkembangan unit } \\
\text { usaha Yayasan Nurul Hayat. }\end{array}$ \\
\hline $\begin{array}{l}\text { Informan III } \\
\text { Bapak }\end{array}$ & $\begin{array}{l}\text { Didapatkan dari } \\
\text { laba unit usaha } \\
\text { aqiqah yang }\end{array}$ & $\begin{array}{l}\text { Bagus, hal ini } \\
\text { dilihat dari } \\
\text { bertambahnya }\end{array}$ & $\begin{array}{l}\text { Laba bersih yang } \\
\text { diperoleh setiap } \\
\text { bulannya }\end{array}$ & $\begin{array}{l}\text { Hasil laba usaha digunakan untuk biaya gaji } \\
\text { karyawan Nurul Hayat dan juga } \\
\text { dipergunakan untuk perkembangan unit }\end{array}$ \\
\hline
\end{tabular}




\begin{tabular}{|c|c|c|c|c|}
\hline \begin{tabular}{|l|} 
Samsul Hadi \\
(Manager \\
Unit Usaha \\
Percetakan \\
Nusa \\
Hikmah \\
Yayasan \\
Nurul Hayat)
\end{tabular} & dipinjamkan & $\begin{array}{l}\text { pendapatan setiap } \\
\text { bulannya. }\end{array}$ & $\begin{array}{l}\text { Rp.30.000.000,- } \\
\text { sampai } \\
\text { Rp.35.000.000,- } \\
\text { dengan omset } \\
\text { Rp.45.000.000,-- }\end{array}$ & $\begin{array}{l}\text { usaha Yayasan Nurul Hayat. Hasil laba usaha } \\
\text { juga digunakan untuk bonus karyawan yang } \\
\text { sudah bekerja selama } 5 \text { tahun untuk umrah. }\end{array}$ \\
\hline $\begin{array}{l}\text { Informan IV } \\
\text { Ibu Istiana } \\
\text { (Adminitrasi } \\
\text { Unit Usaha } \\
\text { Herbalshop } \\
\text { Yayasan } \\
\text { Nurul Hayat) }\end{array}$ & $\begin{array}{l}\text { Didapatkan dari } \\
\text { laba usaha yang } \\
\text { sudah ada. }\end{array}$ & $\begin{array}{l}\text { Usaha herbalshop } \\
\text { ini sudah banyak } \\
\text { diketahui oleh } \\
\text { masyarakat bahwa } \\
\text { Yyayasan Nurul } \\
\text { Hayat menjula } \\
\text { obat herbal. }\end{array}$ & $\begin{array}{l}\text { Laba bersih yang } \\
\text { diperoleh setiap } \\
\text { bulannya } \\
\text { Rp.10.000.000,-- } \\
\text { sampai } \\
\text { Rp.13.000.000,- . }\end{array}$ & $\begin{array}{l}\text { Hasil laba usaha digunakan untuk biaya gaji } \\
\text { karyawan Nurul Hayat dan juga } \\
\text { dipergunakan untuk perkembangan unit } \\
\text { usaha Yayasan Nurul Hayat. }\end{array}$ \\
\hline $\begin{array}{l}\text { Informan V } \\
\text { Ibu Nurrotul } \\
\text { Lailiah } \\
\text { (Manager } \\
\text { Unit Usaha } \\
\text { Aqiaah } \\
\text { Yayasan } \\
\text { Nurul Hayat) }\end{array}$ & $\begin{array}{l}\text { Didapatkan dari } \\
\text { dana hibah } \\
\text { pemilik Yayasan } \\
\text { Nurul Hayat } \\
\text { sebesar } \\
\text { Rp.7.000.000,-. }\end{array}$ & $\begin{array}{l}\text { Bagus, hal ini dapat } \\
\text { dilihat dari cabang } \\
\text { usaha aqiqah yang } \\
\text { tersebar di pulau } \\
\text { Jawa bahkan ada } \\
\text { yang di } \\
\text { Balikpapan. }\end{array}$ & $\begin{array}{l}\text { Omset yang didapat } \\
\text { setiap bulannya bisa } \\
\text { mencapai } \\
\text { Rp.1.000.000.000,-- } \\
\text { sampai } \\
\text { Rp.2.000.000.000,-- }\end{array}$ & $\begin{array}{l}\text { Hasil laba usaha digunakan untuk biaya gaji } \\
\text { karyawan Nurul Hayat dan juga } \\
\text { dipergunakan untuk membuka cabang } \\
\text { usaha di tempat yang lain. }\end{array}$ \\
\hline $\begin{array}{l}\text { Informan VI } \\
\text { Ibu Suheni } \\
\text { Ningsih } \\
\text { (Manager } \\
\text { Keuangan } \\
\text { Yayasan } \\
\text { Nurul Hayat) }\end{array}$ & $\begin{array}{l}\text { Laba usaha yang } \\
\text { didapatkan dari } \\
\text { setiap unit usaha } \\
\text { itu variatif. Total } \\
\text { laba usaha yang } \\
\text { diterima dari } \\
\text { seluruh unit usaha } \\
\text { per bulannya bisa } \\
\text { mencapai } \\
\text { Rp.500.000.000,- } \\
\text { sampai } \\
\text { Rp.800.000.000,- }\end{array}$ & \multicolumn{2}{|c|}{$\begin{array}{l}\text { Hasil laba usaha digunakan untuk biaya } \\
\text { gaji karyawan LAZ Yayasan Nurul Hayat, } \\
\text { mengembangkan usaha atau membuka } \\
\text { cabang usaha pada daerah lain. Laba } \\
\text { usaha juga digunakan untuk bonus } \\
\text { karyawan yang berupa umrah. }\end{array}$} & $\begin{array}{l}\text { Biaya operasional gaji karyawan LAZ setiap } \\
\text { bulannya tidak mencapai Rp.500.000.000,- }\end{array}$ \\
\hline
\end{tabular}




\section{A. Yayasan Nurul Hayat}

Yayasan Nurul Hayat berdiri pada tanggal 7 April tahun 2011, dan pada tahun 2013 sudah menepati usia ke 12. Yayasan Nurul Hayat berdiri pertama kali dengan nama Yayasan Panti Asuhan Nurul Hayat.

Menurut informan I, yaitu Bapak Rama Yuniato, S.H. selaku manajer humas public relation Yayasan Nurul Hayat, Nurul Hayat pertama kali berupa CSR (Corporate Sosial Responsibility). Bapak Mohammad Molik sebagai pendiri Nurul Hayat memiliki CV. Fida Prima, yang bergerak pada bisnis jamu madura. Bapak Mohammad Mohlik mengajak komunitas arisan yang ada dikeluarganya untuk melaksanakan kegiatan sosial. Menyantuni anak yatim piatu merupakan kegiatan sosial yang dilakukan dalam arisan keluarga tersebut. Seiring berjalannya waktu, konsep pemberian tersebut tidak memberdayakan sehingga muncul gagasan untuk mendirikan sebuah panti asuhan yang ditunjang dari CSR jamu Madura dan komunitas arisan kelvarga. Awal mulanya panti asuhan Nurul Hayat berada di daerah Rungkut Kidul yang terdapat 2 sampai 3 orang anak yatim piatu. Pada tahun 2003 Nurul Hayat mulai melibatkan donatur karena berkembangnya panti asuhan Nurul Hayat. Panti Asuhan Nurul Hayat menerbitkan majalah untuk menarik donatur. Pada tahun 2003 ini pun lokasi Nurul Hayat pidah di Perumahan Gunung Anyar Indah.

\section{B. Barang Bekas Berkualitas (BARBEKU)}

Shadaqoh BARBEKU ini adalah barang lama atau barang yang tidak terpakai lagi yang disedekahkan, dan barang lama yang disedekahkan dapat berupa barang yang masih bagus maupun yang sudah rusak. Jadi sedekah di Yayasan Nurul Hayat tidak hanya berupa uang tunai, melainkan bisa berupa barang.

Barang-barang yang disedekahkan akan di bedakan menjadi 2, yaitu yang pertama barang yang siap langsung dijual atau barang tersebut masih dalam kondisi bagus dan layak pakai, yang kedua barang yang disedekahkan harus diperbaiki terlebih dahulu sebelum barang tersebut layak untuk dijual.

Usaha BARBEKU ini tidak memerlukan modal, dikarenakan modal yang diperoleh di dapatkan dari penjualan barang yang masih bagus dan nantinya hasil dari penjualan itu yang akan dipakai untuk memperbaiki barang yang disedekahkan yang perlu perbaikan terlebih dahulu sebelum dijual. Informasi tersebut didapatkan dari bapak Bayu sebagai informan II.

Laba penjualan usaha BARBEKU disetorkan ke Yayasan Nurul Hayat, laba yang di berikan merupakan laba bersih. Bapak bayu sebagi informan II menyatakan, dalam satu bulan unit usaha BARBEKU dapat memperoleh laba bersih kurang lebih sebesar Rp.20.000.000,sampai Rp.30.000.000,- , dengan omset sebesar Rp.40.000.000,-- 


\section{Percetakan Nusa Hikmah}

Menurut informan III, Bapak Samsul Hadi selaku manajer unit usaha percetakan Nusa Hikmah Yayasan Nurul Hayat unit usaha percetakan Nusa Hikmah ini sudah berdiri dari tiga tahun yang lalu. Masalah permodalan untuk membuka unit usaha baru atau membuka cabang. Banyak dipinjamkan dulu dari hasil laba usaha aqiqah. Dapat di perkuat dengan pernyataan Ibu Nurrotul sebagai informan $V$, yaitu "untuk usaha baru kita ambilkan dari usaha aqiaah terlebih dahulu. Dana tersebut dipinjamkan dan nantinya dikembalikan lagi."

Hasil laba yang diperoleh dari percetakan Nusa Hikmah akan disetotkan ke Yayasan Nurul Hayat. Satu bulan usaha ini dapat memperoleh laba bersih kurang lebih sebesar Rp.30.000.000,- sampai Rp.35.000.000,- , dari omset sebesar Rp.45.000.000,-. Hasil dari laba bersih yang diperoleh unit usaha ini, digunakan untuk mengaji karyawan selain divisi unit usaha. Dan laba bersih ini juga digunakan untuk bonus bagi karyawan Yayasan Nurul Hayat yang sudah berkerja minimal lima tahun. Bonus itu berupa umrah yang diadakan setiap tahunnya. Informasi tersebut didapatkan dari informan III, yaitu Bapak Samsul.

\section{HerbalShop}

Herbalshop adalah unit usah yang menjual habattusauda, minyak zaitun, dan madu. Macam yang dijual dalam herbalshop banyak diantaranya, minyak jintan hitam, serbuk jintan hitam baik yang murni ataupun yang ada campurannya.
Minyak zaitun dan beepolen (madu) sering digunakan untuk campuran serbuk jintan hitam. Usaha herbalshop juga menjual sari kurma dan herbal khusus untuk kolesterol, diabet, kanker,dan batuk gurah. Herbalshop ini ada karena adanya majalah Yayasan Nurul Hayat. Informasi tersebut didapatkan dari lbu lis sebgai informan IV.

Ibu lis jga mengatakan bahwa "Modal awal dari unit usaha herbalshop ini dari dana usaha yang dikelola oleh Yayasan Nurul Hayat. Dan dana usaha terpisah dengan dana ZIS yang ada di Yayasan Nurul Hayat. jadi tidak mungkin tercampur antara keuangan usaha dengan ZIS. "

Usaha herbalshop ini dalam sebulam bisa memperoleh laba bersih kurang lebihnya sebesar Rp.10.000.000,sampai Rp.13.000.000,-. Laba bersih yang diperoleh tersebut digunakan untuk membayar gaji karyawan. Tidak hanya karyawan usaha, akan tetapi juga untuk membayar gaji karyawan ZIS. Dan dari sisa laba yang ada, dananya dipergunakan untuk mengembangkan usaha-usaha yang lainnya atau dikelola kembali.

\section{E. Aqiqah}

Usaha aqiqah ini sudah ada sejak tahun 2001, dan usaha ini adalah usaha yang didirikan Nurul Hayat pertama kali. Bapak Rama juga mengatakan "munculah gagasan mendirikan unit usaha, dan unit usaha itu merupakan usaha pertama kali yang didirikan yaitu aqiqoh siap saji." 
Sebelum menjadi Yayasan Nurul Hayat dulunya adalah sebuah panti asuhan yang dikelola secara pribadi oleh Bapak Mohlik. Menurut Ibu Nurrotul sebagai informan $\vee$ "untuk biaya operasional pertama kali, masih ada subsidi dari Bapak Mohlik, maka dari itu beliau mendirikan usaha aqiqah ini."

Ibu Nurrotul mengatakan bahwa awal mula usaha aqiqah ini adalah usaha perorangan, masih belum dibawah yayasan, dan ternyata usaha aqiqah ini berkembang dengan baik. Dilihat dari berkembangnya usaha aqiqah ini, Bapak Mohlik menghibahkan usaha aqiqah Nurul Hayat kepada Yayasan Nurul Hayat. Usaha aqiqah tidak lagi menjadi milik perorangan melaikan menjadi milik Yayasan Nurul Hayat. Untuk modal awal usaha aqiqah ini sebesar Rp.7.000.000,yang diambil dari dana pribadi.

\section{F. Pembahasan}

Yayasan Nurul Hayat merupakan organisasi sosial, yayasan tersebut tidak hanya mendirikan panti asuhan namun juga mengelola dana ZIS yang akan didistribusikan untuk keperluan sosial dan keperluan dakwah. Nurul Hayat juga mendirikan unit usaha, unit usaha ini didirikan dengan tujuan agar yayasan tersebut dapat mandiri dalam membiayai operasional gaji karyawannya.

Yayasan Nurul Hayat tidak mencampur pengelolaan dana ZIS dengan dana unit usaha. Meskipun direktur unit usaha dan ZIS menjadi satu. Akan tetapi untuk manajer keuangannya tidak menjadi satu. Nurul Hayat memiliki dua manajer keuangan yang berbeda, pertama untuk mengatur keuangan ZIS dan yang kedua untuk mengatur keuangan unit usaha yang didirikan oleh Nurul Hayat.

Setiap unit usaha akan mensetorkan laba bersih hasil usahanya kepada Yayasan Nurul Hayat. Hasil laba paling besar diperoleh dari unit usaha aqiaah yang bisa mencapai Rp.500.000.000,- per bulannya hal ini dikemukakan oleh informan ke VI, Yaitu ibu Heni selaku manajer keuangan Yayasan Nurul Hayat. Sedangkan untuk laba bersih yang disetorkan dari unit usaha BARBEKU Bapak bayu sebagai informan II menyatakan "laba bersih BARBEKU bisa mencapai Rp.20.000.000,sampai Rp.30.000.000,--. Untuk unit usaha Percetakan Nusa Hikmah laba bersih yang disampaikan oleh Bapak Samsul sebagai informan III mencapaiRp.30.000.000,sampai Rp.35.000.000,-. Pada unit usaha herbalshop laba yang diperoleh bisa mencapai Rp.10.000.000,- sampai Rp13.000.000,- menurut informan IV, yaitu Ibu lis.

Laba yang diperoleh dari masingmasing unit usaha memang variatif. Akan tetapi jika laba unit usaha secara keseluruhan bisa mencapai rata- rata Rp.531.000.000,-dalam satu bulan pada tahun 2013, sedangkan tahun 2011 dan 2012 laba bersih unit usaha mencapai rata- rata Rp.240.000.000,- dan Rp.280.000.000. Hal ini dapat dilihat dari data tabel berikut. 
Hasil dari laba bersih unit usaha tersebut digunakankan untuk membiayai gaji karyawan ZIS Yayasan Nurul Hayat yang perbulannya tidak mencapai Rp.400.000.000,-. Jadi, Yayasan Nurul Hayat memiliki dua karyawan yaitu, karyawan usaha dan karyawan ZIS. Sebelum laba bersih disetorkan ke Yayasan Nurul Hayat, laba tesrsebut sudah dipotong terlebih dahulu untuk gaji karyawan usaha Yayasan Nurul Hayat dan untuk operasional masing-masing unit usaha. Laba yang disetorkan ke Yayasan Nurul Hayat itu benar-benar sudah bersih dari operasional unit usaha. Data untuk gaji karyawan dapat di lihat pada tabel berikut.

Gaji karyawan sudah diambilkan dari laba usaha, hal ini sangat berdampak positif terhadap pengumpulan dana ZIS. Dana ZIS pada Yayasan Nurul Hayat murni hanya untuk dipergunakan sebagai pengembangan ZIS dan program ZIS. Yayasan Nurul Hayat mempunyai komitmen bahwa yayasan harus mandiri.

Laba unit usaha juga dipergunakan sebagai bonus karyawan Yayasan Nurul Hayat. Bonus tersebut diberikan kepada karyawan berupa biaya umroh. Seperti yang dikatakan oleh informan III, Bapak Samsul bahwa "karywan yang masa kerjanya sudah mencapai 5 tahun akan diberikan bonus dari Nurul Hayat untuk umroh dan dana untuk unmroh di ambil dari laba usaha." Hal ini pun juga dibenarkan oleh lbu Heni sebagai informan VI "setiap tahun ada program umrah untuk karyawan."
Hasil laba unit usaha selain di pergunakan untuk biaya gaji karyawan ZIS, tetapi juga digunakan untuk pengembangan unit usaha. Pengembangan usaha diambil dari sisa surplus laba yang sudah dikurangi oleh gaji karyawan ZIS. Berikut adalah data surplus laba usaha Yayasan Nurul Hayat.

Yayasan Nurul Hayat setiap tahunnya membuka cabang baru minimal dua atau tiga cabang. Perlu dimengerti, cabang yang di buka disini adalah cabang unit usaha bukan cabang ZIS. Sebelum buka cabang ZIS, cabang unit usaha dibuka terlebih dahulu. Dikarenakan agar cabang tersebut dapat mandiri seperti komitmen Yayasan Nurul Hayat dan tanpa menggantungkan cabang lain. Jadi jika cabang unit usaha tersebut sudah mampu mencukupi gaji dan operasional, dan dapat mengaji karyawan ZIS. Maka barulah di buka cabang ZIS di daerah tersebut ini dikemukakan oleh informan ke VI yaitu lbu Heni.

\section{G. Pengelolaan Laba Unit Usaha di Yayasan Nurul Hayat}

Menurut kamus besar bahasa Indonesia, kelola adalah mengurus atau menjalankan, sedangkan pengelolaan adalah proses, cara, perbuatan mengelola. Dapat disimpulkan, bahwa pengelolaan adalah sebuah proses atau cara untuk mengurus atau menjalankan sesuatu agar memiliki nilai lebih dari sebelumnya.

Pengelolaan laba berarti sebuah cara yang dilakukan oleh manager 
keuanagan untuk mengurus laba yang sudah diperoleh dan laba tersebut dapat dimanfaatkan atau dipergunakan secara baik dan benar.

Yayasan Nurul Hayat memisahkan antara kevanagan yang diperoleh dari ZIS dan keuangan yang diperoleh dari unit usaha. Alasan pemisahan tersebut, karena Yayasan Nurul Hayat mempunyai komitmen bahwa yayasan ini harus berdiri secara mandiri. Mandiri yang di maksud disini yaitu, tanpa mengambil dana ZIS untuk keperluan operasional terutama untuk gaji karyawan yang ada di Yayasan Nurul Hayat. Berikut gambar yang menunjukkan pengelolaan laba di Yayasan Nurul Hayat.

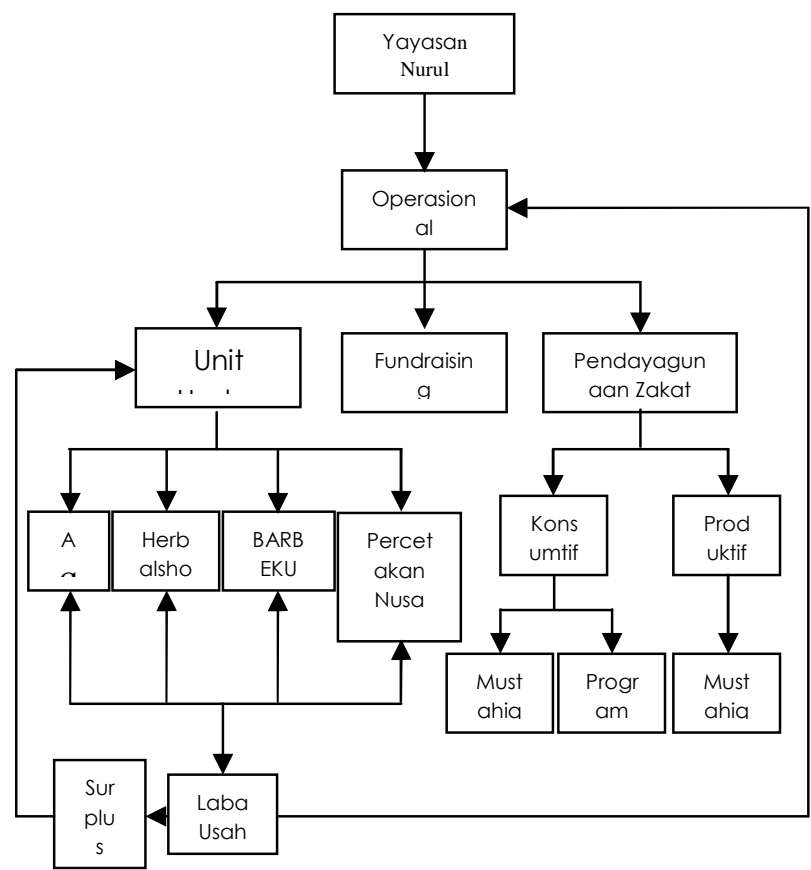

Sumber : Yayasan Nurul Hayat (diolah)

Gambar 1.

Pengelolaan Laba Yayasan Nurul Hayat

Gambar diatas menunjukkan bahwa Yayasan Nurul Hayat memiliki operasional, yang dimana operasional itu bersumber dari unit usaha, fundrising, dan pendayagunaan zakat. Pendayagunaan zakat di berikan secara konsumtif dan produktif. Secara konsumtif dapat di berikan melalui dua cara yaitu langsung kepada mustahia dan di berikan melalui program-program yang dilakukan oleh Yayasan Nurul Hayat. Pendayagunaan produktif diberikan kepada mustahiq. Terdapat empat unit usaha dalam Yayasan Nurul Hayat yaitu, aqiqah, BARBEKU, herbalshop, dan percetakan Nusa Hikmah.Hasil dari laba ini di pergunakan untuk operasional yayasan yang meliputi biaya gaji karyawan dan bonus karyawan. Surplus dari laba usaha digunakan untuk pengembangan unit usaha.

\section{H. Kemampuan Unit Usaha Yayasan Nurul}

\section{Hayat dalam Menunjang Biaya Operasional Lembaga Amil Zakat}

Kemampuan unit usaha Yayasan Nurul Hayat dalam menunjang biaya operasional LAZ dapat dilihat dari laba usaha yang diperoleh yayasan setiap bulannya dapat menutupi beban gaji karyawan LAZ setiap bulannya. Kemampuan ini dapat dilihat dalam tabel berikut

Tabel 3.

Laba Usaha, Biaya Gaji LAZ, Surplus Laba

Tahun 2011

\begin{tabular}{|l|l|l|l|}
\hline Bulan & $\begin{array}{l}\text { Laba } \\
\text { Usaha }\end{array}$ & $\begin{array}{l}\text { Biaya } \\
\text { Gaji LAZ }\end{array}$ & $\begin{array}{l}\text { Surplus } \\
\text { Laba }\end{array}$ \\
\hline Januari & Rp. & Rp. & Rp. \\
& 184.514 .9 & 23.273 .47 & 161.241 .5 \\
& 86 & 6 & 10 \\
\hline Februar & Rp. & Rp. & Rp. \\
\hline
\end{tabular}




\begin{tabular}{|c|c|c|c|}
\hline i & $\begin{array}{l}153.240 .1 \\
74\end{array}$ & $\begin{array}{l}139.183 .6 \\
05\end{array}$ & $\begin{array}{l}14.056 .56 \\
9\end{array}$ \\
\hline Maret & $\begin{array}{l}\text { Rp. } \\
200.105 .3 \\
52\end{array}$ & $\begin{array}{l}\text { Rp. } \\
131.136 .9 \\
00\end{array}$ & $\begin{array}{l}\text { Rp. } \\
68.968 .45 \\
2\end{array}$ \\
\hline April & $\begin{array}{l}\text { Rp. } \\
214.034 .4 \\
32\end{array}$ & $\begin{array}{l}\text { Rp. } \\
152.236 .5 \\
99\end{array}$ & $\begin{array}{l}\text { Rp. } \\
62.397 .83 \\
3\end{array}$ \\
\hline Mei & $\begin{array}{l}\text { Rp. } \\
216.405 .7 \\
45\end{array}$ & $\begin{array}{l}\text { Rp. } \\
140.541 .2 \\
59\end{array}$ & $\begin{array}{l}\text { Rp. } \\
75.864 .48 \\
6\end{array}$ \\
\hline Juni & $\begin{array}{l}\text { Rp. } \\
281.562 .8 \\
55\end{array}$ & $\begin{array}{l}\text { Rp. } \\
138.568 .7 \\
00\end{array}$ & $\begin{array}{l}\text { Rp. } \\
142.994 .1 \\
55\end{array}$ \\
\hline Juli & $\begin{array}{l}\text { Rp. } \\
307.475 .7 \\
16\end{array}$ & $\begin{array}{l}\text { Rp. } \\
138.735 .6 \\
35\end{array}$ & $\begin{array}{l}\text { Rp. } \\
168.740 .0 \\
81\end{array}$ \\
\hline Agustus & $\begin{array}{l}\text { Rp. } \\
109.984 .1 \\
72\end{array}$ & $\begin{array}{l}\text { Rp. } \\
266.433 .2 \\
29\end{array}$ & $\begin{array}{l}\text { Rp. } \\
\text { (156.449. } \\
\text { 057) }\end{array}$ \\
\hline $\begin{array}{l}\text { Septem } \\
\text { ber }\end{array}$ & $\begin{array}{l}\text { Rp. } \\
204.785 .2 \\
90\end{array}$ & $\begin{array}{l}\text { Rp. } \\
156.139 .9 \\
73\end{array}$ & $\begin{array}{l}\text { Rp. } \\
48.645 .31 \\
7\end{array}$ \\
\hline $\begin{array}{l}\text { Oktobe } \\
\text { r }\end{array}$ & $\begin{array}{l}\text { Rp. } \\
287.095 .4 \\
34\end{array}$ & $\begin{array}{l}\text { Rp. } \\
148.431 .9 \\
57\end{array}$ & $\begin{array}{l}\text { Rp. } \\
138.663 .4 \\
77\end{array}$ \\
\hline $\begin{array}{l}\text { Novem } \\
\text { ber }\end{array}$ & $\begin{array}{l}\text { Rp. } \\
299.023 .8 \\
55\end{array}$ & $\begin{array}{l}\text { Rp. } \\
155.632 .7 \\
98\end{array}$ & $\begin{array}{l}\text { Rp. } \\
143.391 .0 \\
57\end{array}$ \\
\hline $\begin{array}{l}\text { Desem } \\
\text { ber }\end{array}$ & $\begin{array}{l}\text { Rp. } \\
400.360 .8 \\
88\end{array}$ & $\begin{array}{l}\text { Rp. } \\
170.560 .8 \\
36\end{array}$ & $\begin{array}{l}\text { Rp. } \\
229.800 .0 \\
52\end{array}$ \\
\hline Jumlah & $\begin{array}{l}\text { Rp. } \\
2.859 .188 \\
.896\end{array}$ & $\begin{array}{l}\text { Rp. } \\
1.760 .874 \\
.967\end{array}$ & $\begin{array}{l}\text { Rp. } \\
1.098 .313 \\
.929\end{array}$ \\
\hline
\end{tabular}

Sumber : Manajer keuangan Yayasan

Nurul Hayat (diolah)
Tabel 4.

Laba Usaha, Biaya Gaji LAZ, Surplus Laba

Tahun 2012

\begin{tabular}{|l|l|l|l|}
\hline Bulan & $\begin{array}{l}\text { Laba } \\
\text { Usaha }\end{array}$ & $\begin{array}{l}\text { Biaya } \\
\text { Gaji }\end{array}$ & Surplus \\
Laba
\end{tabular}




\begin{tabular}{|l|l|l|l|}
\hline & 853 & 851 & \\
\hline Desem & Rp. & Rp. & Rp. \\
ber & 462.118. & 253.845. & 208.273. \\
& 904 & 633 & 271 \\
\hline Jumla & Rp. & Rp. & Rp. \\
h & 3.360 .41 & 2.945 .71 & 414.695. \\
& 2.444 & 6.864 & 580 \\
\hline
\end{tabular}

Sumber : Manajer keuangan Yayasan Nurul Hayat (diolah)

Tabel 5.

Laba Usaha, Biaya Gaji LAZ, Surplus Laba

Tahun 2013

\begin{tabular}{|l|l|l|l|}
\hline Bulan & $\begin{array}{l}\text { Laba } \\
\text { Usaha }\end{array}$ & $\begin{array}{l}\text { Biaya } \\
\text { Gaji }\end{array}$ & $\begin{array}{l}\text { Surplus } \\
\text { Laba }\end{array}$ \\
\hline Januari & Rp. & Rp. & Rp. \\
& 283.279. & 274.546. & 8.732 .707 \\
671 & 964 & \\
\hline Februari & Rp. & Rp. & Rp. \\
& 376.921. & 334.240. & 42.581 .17 \\
& 407 & 235 & 2 \\
\hline Maret & Rp. & Rp. & Rp. \\
& 671.290. & 383.883. & 287.407 .4 \\
& 990 & 512 & 78 \\
\hline April & Rp. & Rp. & Rp. \\
& 505.723. & 344.523. & 161.199 .7 \\
& 349 & 605 & 44 \\
\hline Mei & Rp. & Rp. & Rp. \\
& 612.757. & 416.443. & 196.313 .7 \\
& 410 & 702 & 08 \\
\hline Agustus & Rp. & Rp. & Rp. \\
& 317.281. & 418.917. & $(101.635 .3$ \\
\hline Juni & Rp. & Rp. & Rp. \\
& 722.927. & 374.592. & 348.334 .8 \\
& 429 & 616 & 13 \\
\hline Rp. & Rp. & Rp. \\
& 385.301. & 710.691. & $(325.389 .8$ \\
& 819 & 683 & $64)$ \\
\hline
\end{tabular}

\begin{tabular}{|c|c|c|c|}
\hline & 618 & 002 & 84) \\
\hline $\begin{array}{l}\text { Septem } \\
\text { ber }\end{array}$ & $\begin{array}{l}\text { Rp. } \\
484.913 . \\
384\end{array}$ & $\begin{array}{l}\text { Rp. } \\
378.799 . \\
227\end{array}$ & $\begin{array}{l}\text { Rp. } \\
106.114 .1 \\
57\end{array}$ \\
\hline Oktober & $\begin{array}{l}\text { Rp. } \\
844.633 . \\
039\end{array}$ & $\begin{array}{l}\text { Rp. } \\
382.190 . \\
956\end{array}$ & $\begin{array}{l}\text { Rp. } \\
462.442 .0 \\
83\end{array}$ \\
\hline $\begin{array}{l}\text { Novem } \\
\text { ber }\end{array}$ & $\begin{array}{l}\text { Rp. } \\
573.024 . \\
776\end{array}$ & $\begin{array}{l}\text { Rp. } \\
373.620 . \\
751\end{array}$ & $\begin{array}{l}\text { Rp. } \\
199.404 .0 \\
25\end{array}$ \\
\hline $\begin{array}{l}\text { Desemb } \\
\text { er }\end{array}$ & $\begin{array}{l}\text { Rp. } \\
588.096 . \\
834\end{array}$ & $\begin{array}{l}\text { Rp. } \\
397.369 . \\
855\end{array}$ & $\begin{array}{l}\text { Rp. } \\
190.726 .9 \\
79\end{array}$ \\
\hline \multicolumn{4}{|c|}{ Nurul Hayat (diolah) } \\
\hline
\end{tabular}

dalam menutupi biaya gaji karyawan LAZ Yayasan Nurul Hayat, juga dapat dilihat dalam gambar berikut tentang perbandingan laba usaha, gaji karyawan LAZ, dan surplus laba.

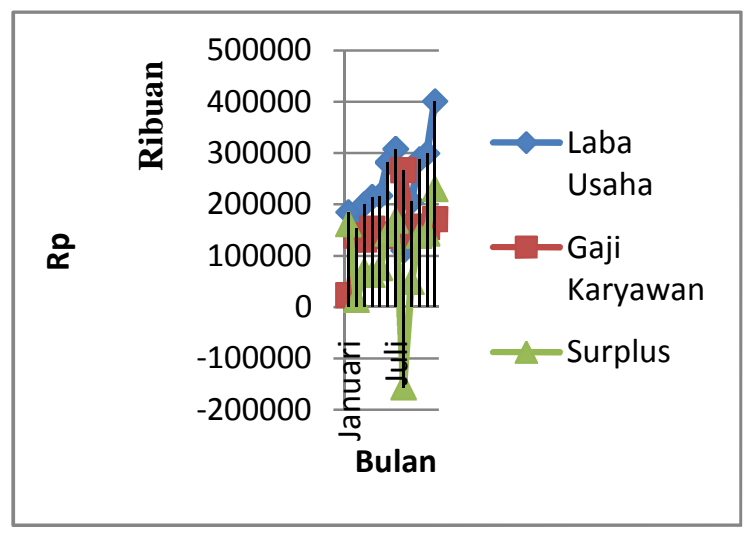

Sumber : Manajer keuangan Yayasan Nurul Hayat (diolah)

Gambar 2.

Perbandingan Laba Usaha, Gaji Karyawan

\section{LAZ, Dan Surpus Laba}

Tahun 2011 
Gambar 2. menunjukkan bahwa pada tahun 2011 pendapatan laba yang ditunjukkan dengan garis berwarna biru, terus meningkat setiap bulannya. Posisi laba usaha selalu berada diatas gaji karyawan LAZ yang ditunjukkan dengan garis berwarna merah, dari hal ini dapat dilihat bahwa unit usaha yang ada dalam Yayasan Nurul Hayat mampu menutupi gaji karyawan LAZ. Pendapatan laba usaha bahkan tidak habis seluruhnya untuk gaji karyawan LAZ, masih ada surplus laba usaha yang ditunjukkan degan garis berwarna hijau. Pada gambar tersebut terjadi penurunan laba usaha pada bulan Agustus, dan untuk gaji karyawan LAZ terjadi kenaikan yang mengakibatkan defisit pada laba. Defisit tersebut dapat ditutupi dengan surplus laba yang diperoleh sebelum bulan Agustus. Penurunan pendapatan pada bulan Agustus dikarenakan pemesanan aqiaah menurun. Yayasan Nurul Hayat hanya melayani pemesanan aqiqah mulai sore hingga malam. Pada bulan Agustus gaji karyawan LAZ sangat meningkat tajam hal ini dikarenakan bonus yang diberikan kepada karyawan Yayasan Nurul Hayat.

Gambar 3. menunjukkan bahwa pada tahun 2012 pendapatan laba yang ditunjukkan dengan garis berwarna biru, terus meningkat setiap bulannya. Posisi gaji karyawan LAZ selalu berada dibawah laba usaha. Gaji karyawan LAZ ditunjukkan dengan garis berwarna merah.

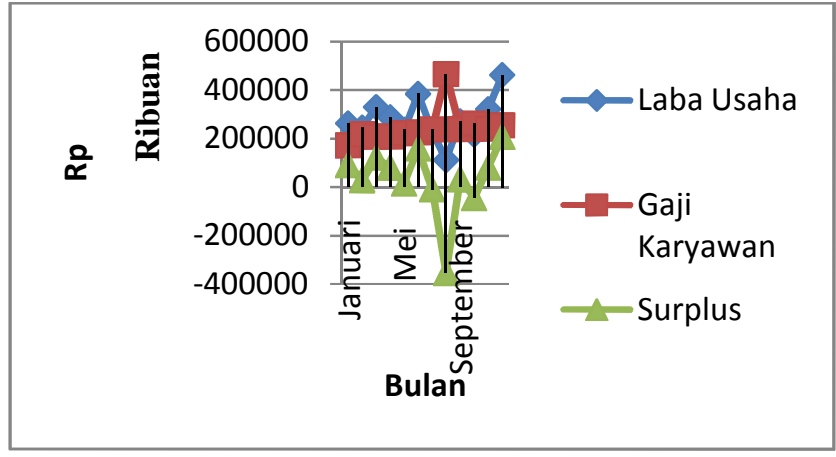

Sumber : Manajer keuangan Yayasan Nurul Hayat (diolah)

\section{Gambar 3.}

\section{Perbandingan Laba Usaha, Gaji Karyawan}

\section{LAZ, Dan Surpus Laba}

Tahun 2012

Adanya hal ini dapat dilihat bahwa unit usaha yang ada dalam Yayasan Nurul Hayat mampu menutupi gaji karyawan LAZ. Pada gambar tersebut terjadi penurunan laba usaha pada bulan Agustus, seperti tahun 2011 juga terjadi penurunan pada bulan Agustus. Penurunan laba usaha ini juga dikarenakan alasan yang sama, yaitu karena pada bulan tersebut bertepatan dengan bulan Ramadhan yang dimana Yayasan Nurul Hayat hanya menerima pemesannya aqiqah pada sore hingga malam hari.

Pada bulan Agustus gaji karyawan LAZ terjadi kenaikan, hal ini dikarenakan Yayasan Nurul Hayat memberikan bonus kepada karyawan LAZ untuk menyambut hari raya. Meskipun pada bulan Agustus terjadi penurunan, Yayasan Nurul Hayat tetap mampu menutupi beban gaji karyawan LAZ pada bulan tersebut. Yayasan Nurul Hayat menggunakan 
surplus laba yang didapatkan sebelum bulan Agustus untuk menutupi beban gaji pada bulan Agustus. Surplus laba ditunjukkan dengan garis berwarna hijau.



Sumber : Manajer keuangan Yayasan

Nurul Hayat (diolah)

Gambar 4.

Perbandingan Laba Usaha, Gaji Karyawan

LAZ, Dan Surpus Laba

Tahun 2013

Gambar diatas tidak jauh berbeda dari tahun tahun sebelumnya, gambar tersebut menunjukkan bahwa pada tahun 2013 pendapatan laba yang ditunjukkan dengan garis berwarna biru, terus meningkat setiap bulannya. Posisi gaji karyawan LAZ selalu berada dibawah laba usaha. Gaji karyawan LAZ ditunjukkan dengan garis berwarna merah, dengan adanya hal ini dapat dilihat bahwa unit usaha yang ada dalam Yayasan Nurul Hayat mampu menutupi gaji karyawan LAZ. Pada tahun 2013 ini penurunan pendapatan laba berbeda dari tahun-tahun sebelumnya, karena penuruan tidak terjadi pada bulan Agustus saja, melaikan bulan Juli dan Agustus, hal ini dapat dilihat pada gambar. Gaji karyawan juga mengalami kenaikan pada bulan Agustus dan Juli.
Untuk alasan penurunan laba usaha yang didapat tetap sama dengan tahun-tahun sebelumnya, yaitu dikarenakan pada bulan Juli dan agustus bertepatan dengan bulan Ramadhan yang dimana pada bulan Ramadhan Yayasan Nurul Hayat akan membatasi pemesanan aqiqah. Kenaikan gaji karyawan LAZ terjadi karena Yayan Nurul Hayat memberikan Bonus THR pada karyawan. Meskipun pada bulan Juli dan Agustus terjadi penurunan, Yayasan Nurul Hayat tetap mampu menutupi beban gaji karyawan LAZ pada bulan tersebut. Yayasan Nurul Hayat menggunakan surplus laba yang didapatkan sebelum bulan Juli untuk menutupi beban gaji pada bulan Agustus. Surplus laba ditunjukkan dengan garis berwarna hijau.

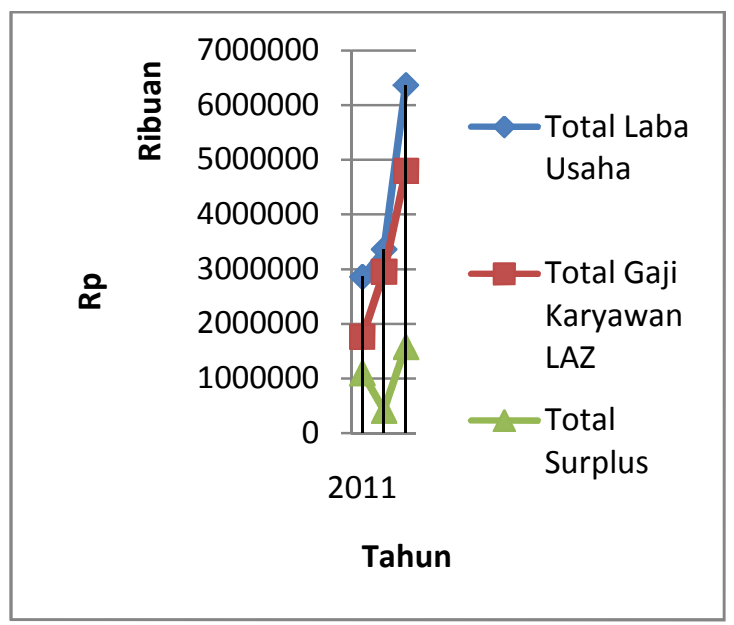

Sumber : Manajer keuangan Yayasan Nurul Hayat (diolah)

Gambar 5.

Perbandingan Laba Usaha, Gaji Karyawan LAZ, Dan Surpus Laba Tahunan

Gambar 5. menunjukkan bahwa posisi total laba usaha yang ditunjukkan dengan garis berwarna biru, selalu diatas 
garis total gaji karyawan LAZ yang berwarna merah. Laba usaha yang didapatpun masih memiliki surplus laba, surplus laba ditunjukka dengan garis berwarnah hijau. Grafik tersebut memperlihatkan bahwa unit usaha Yayasan Nurul Hayat mampu membiayai gaji karyawan LAZ, dan bahkan masih memiliki surplus dari laba yang diterima. Setiap tahunnya gaji karyawan LAZ semakin meningkat, hal ini dikarenakan semakin berkembangnya Yayasan Nurul Hayat. Meskipun gaji karyawan LAZ meningkat laba unit usaha masih bisa menutupi seluruh beban gaji karyawan LAZ Yayasan Nurul Hayat.

\section{Keterbatasan Penelitian}

Penelitian ini hanya dapat memberikan gambaran luas hasil laba usaha yang diperoleh, tanpa merinci pendapatan laba usaha setiap unit usah yang ada pada Yayasan Nurul hayat. Keterbatasan ini dikarena, data yang diminta merupakan data internal Yayasan Nurul Hayat yang tidak boleh dipubikasikan secara rinci.

\section{KESIMPULAN DAN SARAN}

\section{A. SIMPULAN}

Setelah peneliti melakukan penelitian mengenai kemampuan unit usaha untuk menunjang baiya operasional, maka peneliti dapat mengambil kesimpulan berikut:

1. Yayasan Nurul Hayat memiliki kegiatan yang terpisah antara ZIS dan unit usaha. Nurul Hayat tidak mencapur keuangan ZIS dengan keuangan unit usaha, keuangan tersebut dikelola secara terpisah sesuai dengan devisinya.

2. Unit usaha yang ada dalam Yayasan Nurul Hayat dapat membiayai biaya seluruh gaji karyawan yayasan tersebut. Bahkan, masih ada surplus laba yang natinya akan digunakan untuk mengembangakan usaha yang sudah ada, membuka usaha baru, dan membuka cabang usaha di daerah lain.

3. Yayasan Nurul Hayat tidak mengambil hak amil, dikarenakan operasional yang ada diambilkan dari unit usaha yayasan. Dana ZIS yang terkumpul dalam yayasan tersebut seluruhnya hanya digunkan untuk keperluan ummat dan kepentingan dakwah

\section{B. SARAN}

1. Bagi Yayasan Nurul Hayat, sebaiknya tidak mengutamakan unit usaha aqiqah saja dalam perkembangannya, karena juga terdapat unit usaha yang lain yang memiliki potensi yang sama besarnya dengan unit usaha aqiqah dalam menunjang biaya operasional gaji karyawan LAZ.

2. Amil termasuk delapan golongan ashnaf yang berhak memperoleh dana zakat. Meski amil berhak menerima dana zakat, lebih baik jika dana zakat yang diterima amil disalurkan seluruhnya untuk kepentingan ummat dan dakwah.

3. Bagi Lembaga Amil Zakat, dengan adanya Yayasan Nurul Hayat, lembaga-lembaga pengelola dana 
zakat yang lain dapat mencontoh yayasan tersebut untuk tidak mengambil hak amil dan membuka unit usaha agar dapat membiayai operasional yang ada.

4. Bagi penelitian selanjutnya, data yang diminta tidak hanya data unit usaha melainkan juga data LAZ yang ada. Agar dapat melihat lebih jelas lagi manfaat unit usaha Yayasan Nurul Hayat.

\section{DAFTAR PUSTAKA}

Ar-Rifa'i, Muhammad. Nisab. (1999). Ringkasan Tafsir Ibnu Katsir. Jakarta: Gema Isnasi Press.

Ash Shiddiegy, Teungku. Muhammad Hasbi. (2005). Pedoman Zakat. Semarang: Hayam Wuruk.

Fakhruddin. (2008). Fikih dan Manajemen Zakat di Indonesia. Malang: UIN Malang Press.

Hafidhuddin, Didin. (2002). Zakat Dan Peningkatan Kesejahteraan (Upaya Memahami Kembali Makna dan Hakikat Zakat) dalam Mimbar Agama dan Budaya. Jakarta: UIN Syarif Hidayatullah.

Hafidhuddin, Didin. (2003). Panduan Zakat bersama Dr. KH. Didin Hafidhuddin. Jakarta: Republika.

Hikmat, \& Hidayat. (2008). Panduan Pintar Zakat. Jakarta: Qultummedia.

Ja'far, Muhammadiyah (1985). Zakat Puasa dan Haji. Jakarta: Kalam Mulia.

Ja'far, Muhamaddiyah. (2003). Tuntunan Ibadah Zakat, Puasa dan Haji. Jakarta: Kalam Mulia.
Nafarin, M. 2004. Penganggaran Perusahaaan, Edisi Revisi, Salemba Empat, Jakarta.

Purwanto, April. (2009). Manajemen Fundraising bagi Organisasi Pengelola Zakat. Yogyakarta: Sukses.

Qardawi, Yusuf. (1984). Atsar al-Zakat lil afrad wa al-mujtamaat. Seminar Zakat I.

Qardawi, Yusuf. (2004). Hukum Zakat: Studi Komparatif Mengenai Status dan Filsafat Zakat Berdasarkan AlQur'an dan Al-Hadits, terj. Salman Harun, et al. Bogor: PT. Pustaka Litera AntarNusa.

Rais, M. Amien. (1994). Cakrawala Islam antara Cita dan Fakta. Bandung: Mizan.

Rifa'i, Hasan. (1996). Panduan Zakat Praktis, cet.1. Jakarta: Dompet Dhuafa Republika.

Rofiq, Ahmad. (2004). Fiqh Kontekstual: dari Normatif ke Pemaknaan Sosial. Yogyakarta: Pustaka Pelajar.

Shabir, Muslich. (2005). Pemikiran Syekh Muhammad Arsyad Al-Banjari tentang Zakat: Suntingan Teks dan Analisis Intelektual. Jakarta: Nuansa Aulia.

Shihab, M. Quraish. (1992). Membumikan Al-Qur'an: Fungsi dan Peran Wahyu dalam Kehidupan Masyarakat. Bandung: Mizan.

Sudarsono, Heri. (2008). Bank dan Lembaga Kevangan Syariah Deskripsi dan llustrasi. Yogyakarta: Ekonesia. 